\title{
Pengamatan hasil olahan daun beluntas (Pluchea indica L.) terhadap sifat fisika dan kimianya
}

\author{
Observation of the processing results of beluntas (Pluchea indica L.) leaves on their \\ physical and chemical properties
}

\author{
Idiek Donowarti $^{1)}$, Dayang Diah Fidhiani ${ }^{2)}$ \\ ${ }^{1}$ Prodi Agribisnis, Universitas Wisnuwardhana Malang, Malang, Jawa Timur \\ ${ }^{2}$ Sekolah Tinggi Ilmu Perikanan Malang, Malang, Jawa Timur \\ *Email: dayangdiahfidhiani@ gmail.com
}

Info artikel

Dikirim: 16/07/2020; ditinjau: 17/07/2020; disetujui: 20/08/2020

\begin{abstract}
This study was carried out to determine some bioactive phytochemicals in beluntas commonly consumed in Java, Indonesia. It is also to know the effect of fruit processing forward its phytochemicals content. This research comprised two steps including qualitative and quantitative test. The result of qualitative test showed that Pluchea indica L containing of alkaloid and polyphenols. Based on its polyphenols content, Pluchea indica L boiled was the best treatment. The light green variety has total polyphenol value $83,113 \mathrm{mg} / \mathrm{g}$ with the brightness $\left(L^{*}\right)$ and the greeness (a) value are 46,400 and 2,967. Furthermore, the fresh pluchea indica leaf has total polyphenol value $39,135 \mathrm{mg} / \mathrm{g}$ with the brightness ( $\left.L^{*}\right)$ and the greeness (a) value are 46,067 and 2, respectively. Fruit processing intervariety of Pluchea indica $L$ did not give significant effect on water content. Besides, variety and fruit processing did not give significant effect on colour $(b)$. The solute $n$-hexane to analize with thin layer chromatography indicated that this bolied pluchea iindica leaf content terpenoid compound. Bioactive phytochemicals are widely distributed in these foods, although their concentrations are variable among the different types of fruits. These results indicate that this fruits may provide a potential source of dietary antioxidant as a functional food.
\end{abstract}

Keyword: chemical compound, beluntas (pluchea indica)

\begin{abstract}
ABSTRAK
Penelitian ini dilakukan bertujuan untuk menentukan jenis dan total senyawa kimia dalam daun beluntas, serta untuk mengetahui pengaruh proses pengolahan terhadap senyawa kimia tersebut. Penelitian dilaksanakan dalam dua tahap, yakni uji kualitatif dan uji kuantitatif. Hasil penelitian kualitatif menunjukkan bahwa daun mengandung senyawa alkaloid dan polifenol. Berdasarkan kadar polifenol yang diperoleh, beluntas yang di kukus merupakan produk olahan daun beluntas yang paling baik. Pada, produk ini menunjukkan kadar polifenol sebesar $83,113 \mathrm{mg} / \mathrm{g}$ dengan nilai kecerahan ( $\mathrm{L}^{*}$ ) $46,400)$ dan warna hijau (a) $(2,967)$. Sedangkan pada daun beluntas segar menunjukkan kadar polifenol sebesar 39,135 mg/g dengan nilai kecerahan ( $\left.\mathrm{L}^{*}\right)(46,067)$ dan warna hijau (a) (2). Kadar air masing-masing produk olahan antar varietas daun beluntas tidak berbeda nyata. Sementara itu, varietas dan proses pengolahan tidak berpengaruh nyata terhadap warna (b). Ekstrak n-heksana daun beluntas yang di kukus, pada uji KLT dengan penampak noda anisaldehida asam sulfat menunjukkan adanya noda berwarna ungu dan merah ungu. Noda-noda tersebut menunjukkan bahwa daun beluntas yang di
\end{abstract}


kukus mengandung senyawa golongan terpenoid. Hasil penelitian ini diharapkan dapat memberikan informasi mengenai potensi penggunaan daun beluntas sebagai salah satu sumber pangan fungsional.

Kata kunci: Komponen kimiawi, daun beluntas (Pluchea indica)

\section{PENDAHULUAN}

Beluntas merupakan salah satu jenis tanaman yang mudah tumbuh di Indonesia. Hal ini dikarenakan tanaman beluntas sangat cocok tumbuh di Indonesia dan terus berproduksi sepanjang tahun (Rukmana, 1999). Beluntas, secara klinis telah banyak dikenal sebagai tanaman yang digunakan untuk mengatasi berbagai masalah dalam kesehatan, antara lain untuk mengatasi diare, bau badan, reumatik, peluruh demam, nyeri perut, antiimflamation, hal ini disebabkan kandungan berbagai komponen bioaktif dalam beluntas. Di Indonesia, Beluntas selama ini masih dikenal dan dibudidayakan sebatas pada tanaman pagar dan dimanfaatkan sebagai pelengkap makanan pada sebagian kecil masyarakat dengan pengolahan yang sederhana. Beluntas mempunyai sejumlah khasiat yang sangat bermanfaat bagi tubuh. Antara lain menghilangkan bau badan, nyeri perut, mengatasi diare, rematik, peluruh demam, yang disebabkan kandungan komponen bioaktifnya yang sangat beragam. Namun di lain sisi, beluntas belum dimanfaatkan secara optimal, khususnya dalam bidang penyajian keragaman jenis makanan atau kuliner (Astawan, 2007).

Pemanfaatan yang terbatas dan pengolahan yang masih sederhana ini menyebabkan belum optimalnya pemanfaatan komponen bioaktif beluntas sebagai pangan fungsional. (Melo et al. 2006). Menurut Setiawan (2008), beluntas mengandung beberapa zat kimia berkhasiat obat yang diduga adalah minyak atsiri, polifenol, senyawa terpen, klorofil, vitamin C, alkaloid dan tanin. Daun belntas di Thailand saat ini digunakan sebagai tonik saraf dan untuk pengobatan peradangan. Seluruh tanaman digunakan untuk mengobati wasir, sembelit, ulkus aphthous dan batu empedu (Srisook et al., 2012; Neamsuvan dan Ruangrit, 2017). Daun indica pluchea ditemukan memiliki berbagai kegiatan biologis termasuk antioksidan (Widyawati et al., 2014), anti-inflamasi (Buapool et al., 2013), aktivitas hipoglikemik dan antihiperglikemik (Pramanik et al., 2006).

Daun kering dan ekstrak daun beluntas di Thailand telah tersedia secara komersial sebagai teh herbal karena sifat penurun glukosa darah yang dikenal (Suriyaphan, 2014; Widyawati et al., 2015; Sirichaiwetchakoon et al., 2018). Efek antioksidan dan antidiabetes dari P. ekstrak daun indica, laporan ini sebagian besar didasarkan pada bukti aktivitas enzimatik, seperti $\alpha$-glukosidase, $\alpha$-amilase, dan 2, 2diphenyl-1-picryl-hydrazyl-Hydrate (dphh) tes (Noridayu et al., 2011; Arsiningtyas et al., 2014; Vongsak et al., 2018). Enam asam caffeoylquinic di $P$. indica daun dan berpotensi dapat diterapkan untuk digunakan dalam produk herbal komersial (Kongkiatpaiboon, Chewchinda dan Vongsak, 2018)

Ekstrak daun teh daun beluntas juga memiliki kapasitas penghambatan tinggi ketika konsentrasi yang 4-16 lipat pengenceran. Ekstrak akar segar memiliki potensi penghambatan yang paling baik terhadap Bacillus cereus, Pseudomonas fluorescens dan Salmonella typhimurium $(0,16,0,16$ dan $0,32 \mathrm{mg} / \mathrm{mL}$ MICs, masingmasing). Kegiatan penghambatan terhadap Escherichia Coli sangat rendah. Peningkatan aktivitas antioksidan tidak meningkatkan kemampuan antibakteri (Srimoon dan Ngiewthaisong, 2015), menghambat pertumbuhan Propionibacterium acnes (Hafsari et al., 2015) dan menurunkan glukosa darah secara in vivo (Nopparat, Nualla-Ong dan Phongdara, 2019). Penelitian ini bertujuan untuk menentukan jenis dan total senyawa kimia dalam daun beluntas dan pengaruh proses pengolahan terhadap senyawa kimia tersebut 


\section{METODE}

\section{Bahan dan alat}

Bahan utama yang digunakan dalam penelitian ini adalah daun beluntas segar (berat rata-rata $300 \mathrm{~g}$ ) yang diperoleh dari pedagang daun beluntas di pasar Kota Batu.

Bahan yang diperlukan untuk analisa kimia (uji kualitatif dan kuantitatif) meliputi larutan metanol $80 \%$ p.a., aquades, benzena, reagen Dragendorf, kloroform, $\mathrm{FeCl}_{3}, \mathrm{NaOH}$ $2 \mathrm{~N}$., $\mathrm{HCl} 2 \mathrm{~N}$ p.a., $\mathrm{H}_{2} \mathrm{SO}_{4} 2 \mathrm{~N}, \mathrm{Na}_{2} \mathrm{CO}_{3}$, reagen Folin Ciocalteu, serbuk seng dan alumminium foil.

Peralatan yang digunakan ekstrak daun beluntas dan olahannya antara lain beker glass $100 \mathrm{~mL}$, hot plate stirer, erlenmeyer $100 \mathrm{~mL}$ dan kertas saring. Sedangkan peralatan lain yang digunakan untuk analisa fisik dan kimia antara lain neraca digital merk "Mettler Tolledo", oven, spektrofotometer merk "UNICO UV-2100", desikator, "color reader" merk "MINOLTA CR-10", "vortex" merk "Vortex-Mixer" model VM-200, beker glass $100 \mathrm{~mL}$, pipet volume $2 \mathrm{~mL}$, pipet ukur $10 \mathrm{~mL}$, erlenmeyer $100 \mathrm{~mL}$, beker glass $250 \mathrm{~mL}$, gelas ukur 100 $\mathrm{mL}$, pipet tetes, labu ukur $100 \mathrm{~mL}$, petridish, tabung reaksi, rak tabung reaksi, spatula, pengaduk gelas, corong gelas dan papan tetes porselen.

\section{Pembuatan ekstrak daun beluntas segar (kontrol)}

Daun beluntas segar di sortasi (berat $300 \pm 10$ g) dan dicuci dengan air mengalir untuk menghilangkan kotoran. Kulit dikupas dengan pisau dan dipotong-potong dengan ukuran $\pm 3 \mathrm{~cm}$ kemudian diblender. diambil sebagian dan dipotong kecil-kecil untuk uji tanin secara kualitatif.

Bubur (slurry) ditimbang sebanyak 10 g kemudian di ekstraksi (2 kali) secara maserasi, masing-masing menggunakan pelarut metanol $80 \%$ sebanyak $30 \mathrm{~mL}$ selama 20 menit (Melo et al., 2006)). Ekstrak kasar yang diperoleh diuji secara kualitatif untuk mengetahui adanya kandungan alkaloid dan saponin. Ekstrak jernih (setelah penyaringan) diuji secara kualitatif (polifenol flavonoid dan antrakuinon) dan secara kuantitatif untuk mengetahui kadar polifenol.

\section{Pembuatan daun beluntas rebus}

Daun beluntas segar di sortasi (berat $300 \pm 10 \mathrm{~g}$ ) dan dicuci dengan air mengalir untuk menghilangkan kotoran. Kulit dikupas dengan pisau dan dipotong menjadi empat bagian kemudian dimasukkan panci berisi air mendidih. Perebusan dilakukan selama 20 menit. diangkat dan ditiriskan agar dingin. Produk di ekstrak seperti pada pembuatan kontrol.

\section{Pembuatan jus daun beluntas}

Daun beluntas segar di sortasi (berat 300 $\pm 10 \mathrm{~g}$ ) dan dicuci dengan air mengalir untuk menghilangkan kotoran. Kulit dikupas dengan pisau dan dipotong-potong dengan ukuran $\pm 3 \mathrm{~cm}$ lalu dimasukkan mesin "juicer" untuk memperoleh sari daun beluntas. Produk di ekstrak seperti pada pembuatan kontrol.

\section{Uji kualitatif komponen kimiawi daun beluntas dan produk olahannya}

\section{Deteksi alkaloid}

Larutan ekstrak diambil $2 \mathrm{~mL}$ lalu ditambah $5 \mathrm{~mL}$ larutan HCL $2 \mathrm{~N}$, dipanaskan selama \pm 3 menit, disaring, ditambahkan lagi $\mathrm{HCl} 2 \mathrm{~N}$ lhingga volume $10 \mathrm{~mL}$, dicuci dengan n-heksana kemudian dengan kloroform. Pada fase asam ditambahkan ammonium hidroksida dan di ekstraksi dengan larutan kloroform. Fase organik yang terbentuk dipisahkan kemudian diuji dengan pereaksi Dragendorf. Uji menunjukkan reaksi positif jika muncul endapan berwarna merah kecokelatan/oranye (Kristanti dan Nanik, 2001).

\section{Deteksi polifenol dengan kromatografi lapis tipis (KLT) (Vessal et al., 2000)}

Sampel dihancurkan dan ditimbang 10 gram, di ekstraksi dengan $60 \mathrm{~mL}$ asam asetat $10 \%$ dalam etanol selama \pm 4 jam. Pelarut diuapkan dengan Rotary Vacuum Evaporator sampai tinggal $1 / 4$ volume awal. Alkaloid diendapkan dengan meneteskan $\mathrm{NH}_{4} \mathrm{OH}$ pekat. Endapan dikumpulkan dengan cara pemusingan lalu cuci dengan $\mathrm{NH}_{4} \mathrm{OH} 1 \%$. Larutkan sisa dalam beberapa tetes etanol dan dikromatografi pada plat silica gel $G$ 
dalam metanol $-\mathrm{NH}_{4} \mathrm{OH}$ pekat $(200: 3)$. Deteksi adanya alkaloid pada plat, mulamula dengan fluorosensi di bawah sinar UV kemudian disemprot dengan pereaksi Dragendoff. Alkaloid nampak sebagai spot dalam warna kuning (Miller and Woodrow, 2004).

\section{Deteksi polifenol}

Larutan ekstrak diambil $2 \mathrm{~mL}$ lalu ditambah 2 mL larutan besi (III) klorida $1 \%$. Uji menunjukkan reaksi positif jika timbul warna hijau, merah, ungu, biru, atau hitam yang kuat (Harborne, 1996).

\section{Deteksi flavonoid}

Larutan ekstrak diambil $2 \mathrm{~mL}$, ditambah sedikit serbuk seng lalu ditambah 2 $\mathrm{mL} \mathrm{HCl} 2 \mathrm{~N}$. Uji menunjukkan reaksi positif jika timbul warna jingga hingga merah (Hanani, et al., 2001).

\section{Deteksi saponin}

Larutan ekstrak dikocok. Uji menunjukkan reaksi positif jika timbul busa yang tahan lama (30 menit) pada permukaan cairan (Harborne, 1996).

\section{Deteksi tanin}

Sampel dipotong-potong dan dimasukkan ke dalam tabung reaksi, ditambah $2 \mathrm{~mL} \mathrm{HCl} 2 \mathrm{M}$, dihidrolisis pada air mendidih selama 30 menit. Uji menunjukkan reaksi positif jika timbul warna merah pada larutan (Harborne, 1996).

\section{Deteksi antrakuinon}

Larutan ekstrak diambil $2 \mathrm{~mL}$, ditambah $5 \mathrm{~mL}$ larutan $\mathrm{H}_{2} \mathrm{SO}_{4}$, dipanaskan selama 1 menit, didinginkan, ditambah $10 \mathrm{~mL}$ bensen dan dikocok. Uji menunjukkan reaksi positif jika timbul warna kuning pada lapisan benzen dengan fluorosensi hijau. Identifikasi dapat diperjelas dengan menambahkan larutan $\mathrm{NaOH} 2 \mathrm{~N}$ dimana akan terbentuk warna merah pada lapisan air (Hanani, et al., 2001).

\section{Uji kuantitatif komponen kimiawi daun beluntas dan produk olahannya}

\section{Pengukuran kadar air}

Sampel ditimbang 5 gram dan dimasukkan ke dalam cawan yang sudah dikonstankan, dikeringkan dalam oven $\left( \pm 105^{\circ} \mathrm{C}\right)$ selama 4 jam, dinginkan dalam desikator $( \pm 15$ menit $)$ lalu ditimbang. Dikeringkan kembali hingga diperoleh berat konstan (selisih antarpenimbangan <0,2 $\mathrm{mg}$ ) (Apriyantono et al., 1989).

$$
\begin{aligned}
& \text { Berat awal }=\mathrm{W}_{1} \\
& \text { Berat akhir }=\mathrm{W}_{2} \\
& \text { Kehilangan berat }=\mathrm{W}_{3} \\
& \text { Kadar Air }(\%)=\left(\mathrm{W}_{3} / \mathrm{W}_{1}\right) \times 100 \%
\end{aligned}
$$

\section{Pengukuran total polifenol}

$1 \mathrm{ml}$ ekstrak sampel (supernatan) ditambah $4 \mathrm{ml}$ reagen Folin Ciocalteu, ditambah $5 \mathrm{ml} \mathrm{Na}_{2} \mathrm{CO}_{3} 2 \%$, divortex, didiamkan \pm 30 menit kemudian diukur absorbansinya dengan spektrofotometer pada $\lambda=760 \mathrm{~nm}$. Perhitungan kadar polifenol yang terekstrak didasarkan pada kurva standar asam galat (Tang, et al., 2002 dalam Lydia, et al., 2003).

\section{Pengukuran warna}

Sampel dimasukkan dalam kantong plastik yang bening lalu dilakukan pengukuran dengan colour reader (Yuwono dan Susanto, 1998).

\section{Analisa statistik}

Data yang diperoleh akan dianalisis dengan analisis ragam (ANNOVA) dengan selang kepercayaan 1\% dan 5\%. Dilanjutkan dengan uji Beda Nyata Jujur (BNJ) untuk masing-masing faktor perlakuan dengan selang kepercayaan $5 \%$.

\section{HASIL DAN PEMBAHASAN}

\section{Analisa fisik}

\section{Analisa warna $L^{*}$}

$\mathrm{L}^{*}$ adalah komponen "luminance" atau lightness. Nilai L* (kecerahan) menyatakan tingkat gelap terang dengan kisaran 0 sampai 100. Dimana nilai 0 menyatakan kecenderungan warna hitam atau sangat gelap, sedangkan nilai 100 menyatakan kecenderungan warna putih atau terang (Yuwono dan Susanto, 1998).

Warna $\mathrm{L}^{*}$ atau tingkat kecerahan pada analisa daun beluntas berkisar antara 33,43 sampai 46,4. Pengaruh proses pengolahan daun beluntas terhadap nilai warna $\mathrm{L}^{*}$ dapat dilihat pada gambar di bawah ini. 


\section{intensitas warna $L^{*}$}

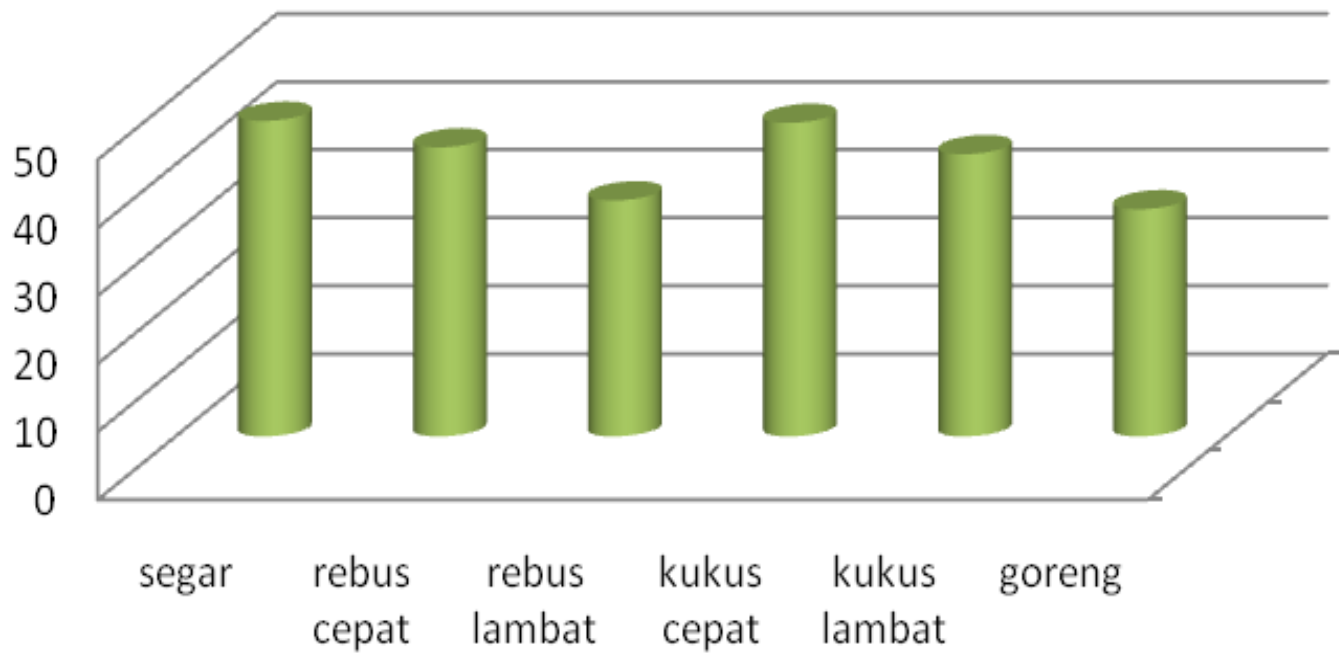

Gambar 1. Rerata nilai warna $L^{*}$ daun beluntas akibat pengolahan

Berdasarkan grafik (gambar 1) nilai warna $\mathrm{L}^{*}$ terendah terlihat pada kukus daun beluntas segar. Hasil analisa ragam menunjukkan tingkat kecerahan yang berbeda nyata antara daun beluntas hijau tua dan hijau muda. Nilai kecerahan daun beluntas hijau muda lebih tinggi $(41,21111)$ dibandingkan daun beluntas hijau tua (40,34444). Semakin rendah nilai kecerahan maka warna daun semakin gelap, demikian pula sebaliknya.

Rerata nilai warna $L^{*}$ (kecerahan) untuk produk-produk hasil pengolahan daun beluntas disajikan pada tabel 1 Berdasarkan tabel di bawah diperoleh nilai tertinggi tingkat kecerahan pada kukus daun, yakni kukus daun beluntas hijau tua dengan nilai 33,433. Sedangkan nilai kecerahan terendah terdapat pada produk pasta segar daun beluntas dengan nilai 46,067.

Hasil analisa ragam menunjukkan bahwa proses pengolahan daun beluntas memberikan pengaruh nyata terhadap tingkat kecerahan. Namun, pada produk pasta segar diperoleh notasi yang sama yang menunjukkan bahwa produk pasta segar daun beluntas dari dengan tidak berbeda nyata.
Tabel 1. Rerata nilai warna $L^{*}$ daun beluntas akibat pengolahan

\begin{tabular}{lc}
\hline \multicolumn{1}{c}{ Perlakuan } & Notasi \\
\hline Segar & $46,4(\mathrm{e})$ \\
Rebus Cepat & $42,5(\mathrm{~d})$ \\
Rebus Lambat & $34,73333(\mathrm{~b})$ \\
Kukus Cepat & $46,06667(\mathrm{de})$ \\
Kukus Lambat & $41,53333(\mathrm{c})$ \\
Goreng & $33,43333(\mathrm{a})$ \\
\hline BNJ 5\%=0,608537500171869 \\
\hline
\end{tabular}

Keterangan: Rerata yang didampingi huruf yang berbeda menunjukkan pengaruh yang nyata pada taraf $(\alpha=0,05)$

Selama proses pemasakan, terjadi reaksi kimia yang menyebabkan perubahan warna dan tekstur. Warna hijau pada sayuran berkaitan erat dengan pigmen klorofil (Blumenthal, 2008).

Blumenthal (2008) menjelaskan bahwa selama pemasakan, ion magnesium $\left(\mathrm{Mg}^{2+}\right)$ dalam struktur molekul klorofil dapat digantikan oleh 2 ion $\mathrm{H}^{+}$dan membentuk senyawa baru yang disebut fenofitin. Senyawa ini menimbulkan warna hijau pudar atau cokelat pada sayur yang telah dimasak. 
Oleh sebab itu warna sayuran yang telah dimasak cenderung pudar (pucat).

Dalam "Chemistry Specimen Paper" (2002) juga dijelaskan bahwa ion $\mathrm{Mg}^{2+}$ dalam struktur klorofil dapat digeser oleh ion logam lainnya seperti ion $\mathrm{Cu}^{2+}$ yang dapat menimbulkan warna biru kehijauan dengan feofitin. Jika $\mathrm{pH}$ terlalu tinggi, misalnya $\mathrm{pH}$ 10 maka fitil ester cenderung terhidrolisa sehingga klorofil menjadi larut dalam air. Akibatnya, sayuran yang direbus menjadi pucat karena cukup banyak kehilangan klorofil.

\section{Analisa warna $a^{*}$}

Trend warna $\mathrm{a}^{*}$ menunjukkan warna dari hijau ke merah. Komponen warna ini memiliki nilai berkisar antara -100 sampai 100. Nilai warna $a^{*}$ positif menyatakan warna merah dan nilai warna $a^{*}$ negatif menyatakan warna hijau.

Rerata nilai warna $a^{*}$ daun beluntas berkisar antara 0,6 sampai 3,53. Hal ini berarti warna daun beluntas cenderung hijau. Pengaruh proses pengolahan daun beluntas terhadap nilai warna $a^{*}$ dapat dilihat pada gambar 2.

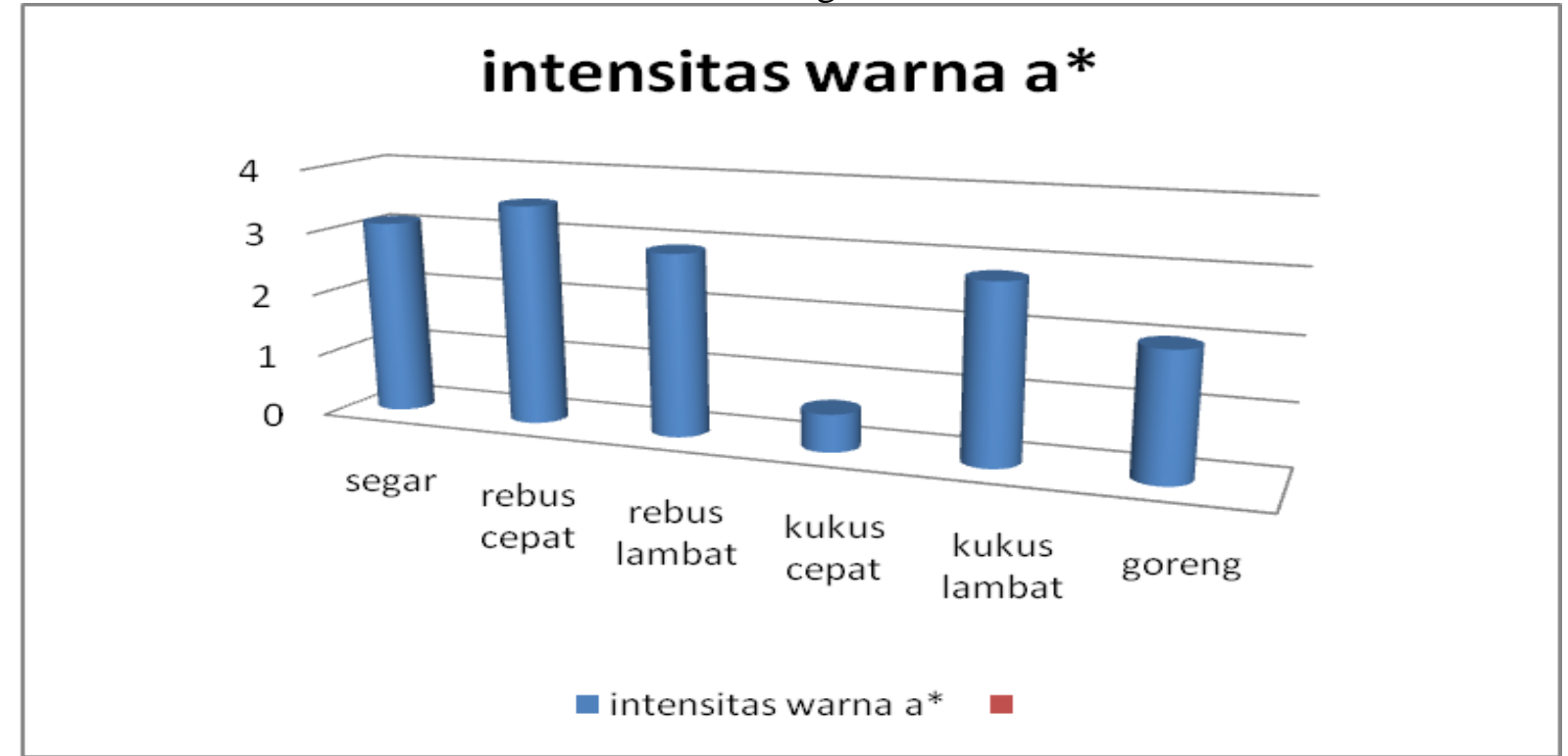

Gambar 2. Rerata nilai warna a* daun beluntas akibat pengolahan

Berdasarkan grafik di atas nilai warna a* terendah terletak pada pasta daun beluntas segar. Nilai warna $a^{*}$ daun beluntas hijau muda lebih tinggi $(3,222222)$ dibandingkan daun beluntas hijau tua $(1,811111)$. Semakin rendah nilai warna $\mathrm{a}^{*}$ maka warna daun semakin mendekati warna hijau. Hal ini berarti daun beluntas berwarna hijau terang. Hasil analisa ragam menunjukkan warna $a^{*}$ yang berbeda nyata antara daun beluntas hijau tua dan hijau muda.

Warna hijau pada sayuran berkaitan erat dengan pigmen klorofil (Blumenthal, 2008). Upaya mempertahankan warna hijau pada sayur yang disebabkan oleh keberadaan pigmen klorofil sangat diinginkan oleh konsumen dan produsen produk sayur olahan yang menggunakan proses panas (Gaur et al., 2006). Rerata nilai warna $a^{*}$ untuk produk- produk hasil pengolahan daun beluntas disajikan pada tabel 2 .

Tabel 2. Rerata nilai warna a* daun beluntas akibat pengolahan

\begin{tabular}{lc}
\hline \multicolumn{1}{c}{ Perlakuan } & nilai tengah \\
\hline Segar & $3,166667(\mathrm{e})$ \\
Rebus Cepat & $3,533333(\mathrm{e})$ \\
Rebus Lambat & $2,966667(\mathrm{~cd})$ \\
Kukus Cepat & $0,6(\mathrm{a})$ \\
Kukus Lambat & $2,833333(\mathrm{bc})$ \\
Goreng & $2(\mathrm{~b})$ \\
\hline BNJ 5\% $=0,303185250789487$ \\
\hline
\end{tabular}

Keterangan: rerata yang didampingi huruf yang berbeda menunjukkan pengaruh yang nyata pada taraf $(\alpha=0,05)$

Berdasarkan tabel di atas diperoleh nilai warna $a^{*}$ tertinggi pada pasta daun beluntas rebus, yakni daun beluntas hijau 
muda dengan nilai 3,533 . Sedangkan nilai warna $a^{*}$ terendah terdapat pada produk pasta segar daun beluntas hijau tua dengan nilai 0,6. Hasil analisa ragam menunjukkan bahwa proses pengolahan daun beluntas memberikan pengaruh yang nyata terhadap nilai warna $a^{*}$ (intensitas warna hijau).

Pada proses pengolahan perebusan, intensitas warna $a^{*}$ mengalami peningkatan. Hal ini menunjukkan warna produk olahan daun beluntas semakin cerah. Penurunan warna hijau ini disebabkan adanya proses pemanasan selama perebusan sehingga klorofil dalam daun mengalami kerusakan. Ion magnesium $\left(\mathrm{Mg}^{2+}\right)$ dalam struktur molekul klorofil dapat digantikan oleh 2 ion $\mathrm{H}^{+}$dan membentuk senyawa baru yang disebut fenofitin. Senyawa ini menimbulkan warna hijau pudar atau cokelat pada sayur yang telah dimasak (Blumenthal, 2008).

Dalam "Chemistry Specimen Paper" (2002) juga dijelaskan bahwa ion $\mathrm{Mg}^{2+}$ dalam struktur klorofil dapat digeser oleh ion logam lainnya seperti ion $\mathrm{Cu}^{2+}$ yang dapat menimbulkan warna biru kehijauan dengan feofitin. Jika $\mathrm{pH}$ terlalu tinggi, misalnya $\mathrm{pH}$ 10 maka fitil ester cenderung terhidrolisa sehingga klorofil menjadi larut dalam air. Akibatnya, sayuran yang direbus menjadi pucat karena cukup banyak kehilangan klorofil.

Sedangkan pada produk kukus daun beluntas, penurunan warna hijau tidak sebesar pada proses perebusan. Hal ini dikarenakan dalam proses pembuatan kukus tidak menggunakan pemanasan. Warna produk merupakan pigmen klorofil yang terbawa saat proses ekstraksi.

Weemaes et al. (1999) menyatakan bahwa pemasakan sayuran menyebabkan degradasi klorofil $a$ dan $b$ menjadi feofitin $a$ dan $b$, berturut-turut dan klorofil $a$ memiliki sifat lebih sensitif terhadap panas dibanding klorofil $b$.

\section{Analisa warna $b^{*}$}

Nilai warna $b^{*}$ menunjukkan warna dari biru ke kuning. Tingkat warna $b^{*}$ berkisar antara -100 sampai 100. Nilai positif menunjukkan intensitas warna kuning dan nilai negatif menunjukkan intensitas warna biru (Lawless dan Heyman, 1998).

Rerata nilai warna $b^{*}$ daun beluntas berkisar antara 14.333 sampai 24,933. Hal ini berarti warna daun beluntas cenderung ke arah warna kuning. Pengaruh proses pengolahan daun beluntas terhadap nilai warna $b^{*}$ dapat dilihat pada gambar 3 .

\section{Intensitas warna b*}

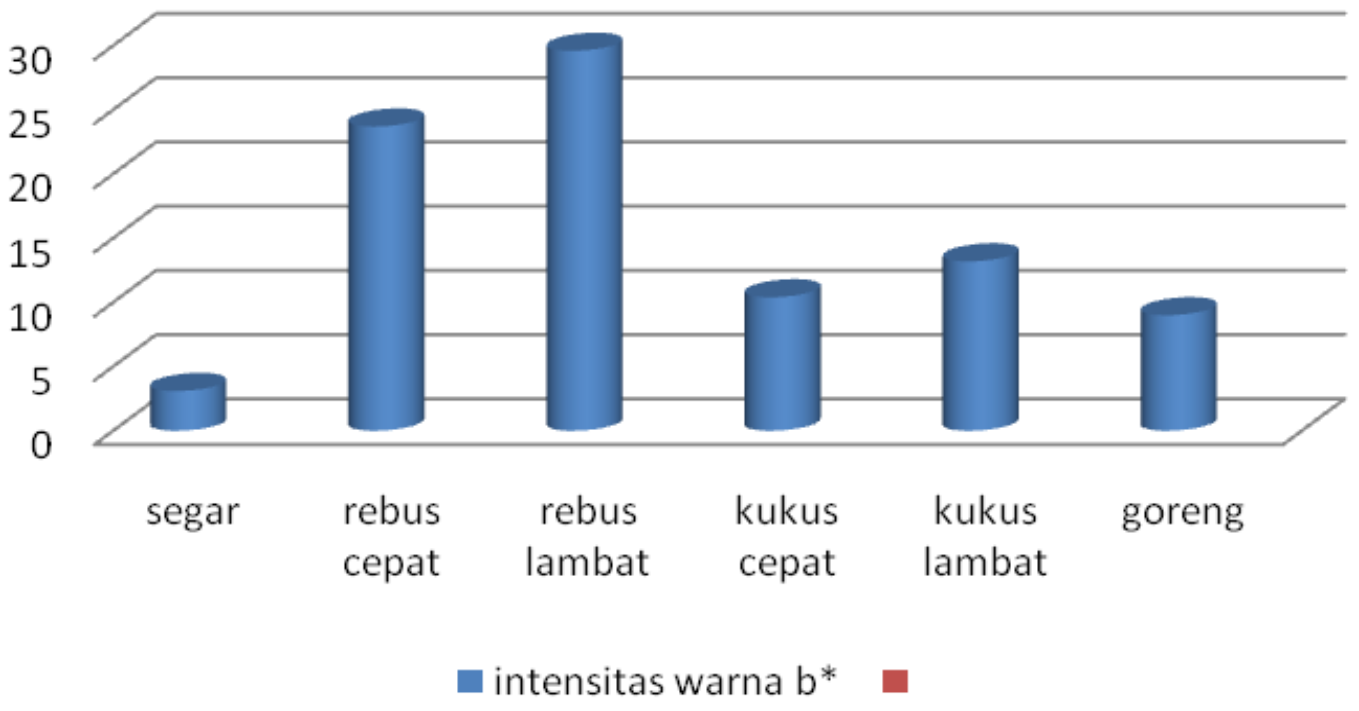

Gambar 3. Rerata nilai warna $b^{*}$ daun beluntas akibat pengolahan 
Berdasarkan grafik di atas nilai warna b* tertinggi terletak pada pasta daun beluntas segar. Nilai warna $b^{*}$ daun beluntas hijau tua lebih tinggi $(20,589)$ dibandingkan daun beluntas hijau muda $(16,378)$. Semakin tinggi nilai warna $b^{*}$ maka warna daun semakin mendekati warna kuning. Hasil analisa ragam menunjukkan warna $b^{*}$ yang berbeda nyata antara daun beluntas hijau tua dan hijau muda.

Rerata nilai warna $a^{*}$ untuk produkproduk hasil pengolahan daun beluntas disajikan pada tabel 3 .

Tabel 3. Rerata nilai warna $b^{*}$ daun beluntas akibat pengolahan

\begin{tabular}{lc}
\hline \multicolumn{1}{c}{ Perlakuan } & nilai tengah \\
\hline Segar & 3,56667 (c) \\
Rebus Cepat & $23,73333(\mathrm{~b})$ \\
Rebus Lambat & 29,63333 (a) \\
Kukus Cepat & $10,43333(\mathrm{e})$ \\
Kukus Lambat & $13,23333(\mathrm{~d})$ \\
Goreng & $9.0(\mathrm{~b})$ \\
\hline
\end{tabular}

BNJ 5\% = 0,133257

Keterangan: rerata yang didampingi huruf yang berbeda menunjukkan pengaruh yang nyata pada taraf $(\alpha=0,05)$

Berdasarkan tabel 3 diperoleh nilai warna $b^{*}$ tertinggi pada pasta daun beluntas segar, yakni daun beluntas hijau tua dengan nilai 24,933. Sedangkan nilai warna $b^{*}$ terendah terdapat pada produk kukus daun beluntas hijau tua dengan nilai 15 . Hasil analisa ragam menunjukkan bahwa proses pengolahan daun beluntas memberikan pengaruh yang berbeda nyata terhadap nilai warna $b^{*}$ (intensitas warna kuning).

Pada proses pengolahan perebusan, intensitas warna $b^{*}$ mengalami penurunan. Hal ini menunjukkan warna produk olahan daun beluntas semakin cerah. Pemucatan ini disebabkan adanya proses pemanasan selama perebusan sehingga pigmen yang menyusun warna dalam daun mengalami kerusakan. Seperti yang dijelaskan Blumenthal (2008) bahwa pada perebusan sayur, ion $\mathrm{H}^{+}$dapat menggeser tempat ion magnesium $\left(\mathrm{Mg}^{2+}\right)$ dalam struktur molekul klorofil membentuk senyawa baru yang disebut fenofitin. Senyawa ini menimbulkan warna hijau pudar atau cokelat pada sayur yang telah dimasak.

Dalam "Chemistry Specimen Paper" (2002) juga dijelaskan bahwa kemungkinan adanya ion logam lainnya seperti ion $\mathrm{Cu}^{2+}$ dapat menggeser ion $\mathrm{Mg}^{2+}$ dalam struktur klorofil dapat menimbulkan warna biru kehijauan dengan feofitin. Jika $\mathrm{pH}$ terlalu tinggi, misalnya $\mathrm{pH} 10$ maka fitil ester cenderung terhidrolisa sehingga klorofil menjadi larut dalam air. Akibatnya, sayuran yang direbus menjadi pucat karena klorofilnya larut dalam air.

Sedangkan pada produk kukus daun beluntas, nilai warna kuning hampir sama. Hal ini dikarenakan dalam proses pembuatan kukus tidak menggunakan pemanasan. Warna produk merupakan pigmen yang terbawa saat proses ekstraksi.

Dari pengamatan warna, didapat bahwa beluntas dengan pengolahan direbus dengan waktu cepat (15 menit) mempunyai warna lebih hijau dibanding perlakuan pengolahan yang lain, sedang beluntas yang di kukus lama, mempunyai warna yang paling pucat, hal ini sesuai dengan pengamatan terhadap sisa air dari pengolahan dengan di kukus, didapat warna air yang kehujauan. Pada pengolahan dengan dirrebus cepat, sisa air perebusan berwarna kuning bening, sedang pada perebusan lambat (30 menit), diperoleh warna daun yang lebih kekuningan dengan sisa air perebusan berwarna kuning keruh.

Pada pengolahan dengan pengukusan, warna daun beluntas pucat dan lebih pucat pada pengukusan lama, sedang sisa air pengukusan berwarna kehijauan dan menjadi lebih hijau pada pengukusan lama

Pengamatan terhadap aroma, pengamatan didapat bahwa aroma yang paling harum diperoleh dengan pengukusan cepat (30 menit), sedang aroma yang paling tidak bagus diperoleh pada hasil pengolahan direbus lama. 


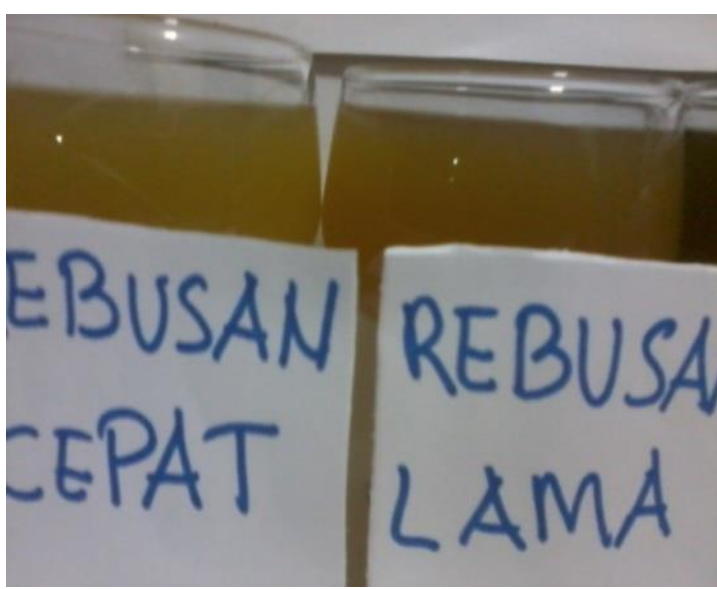

a

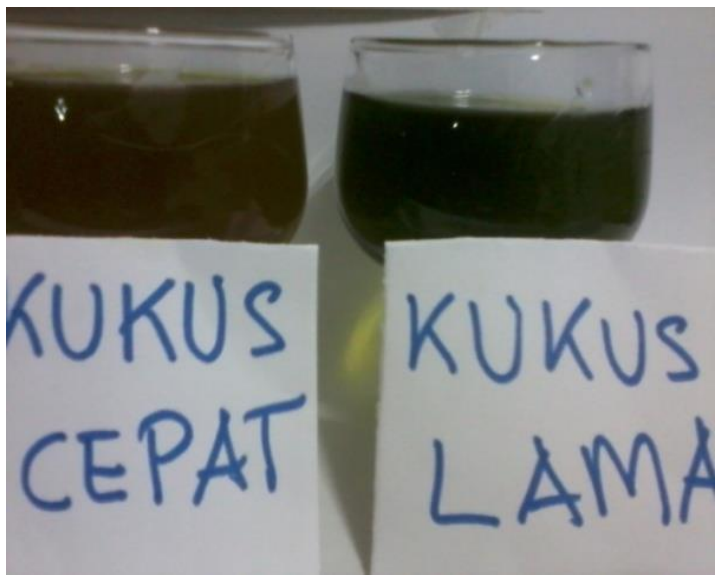

c

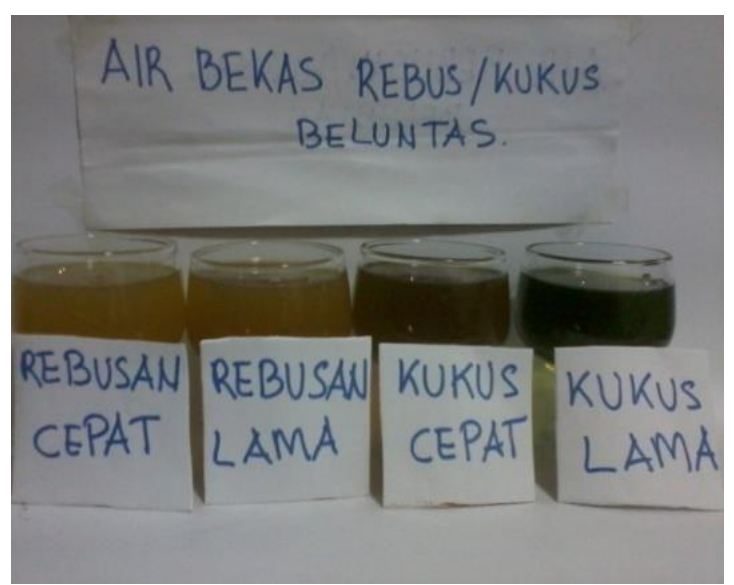

b

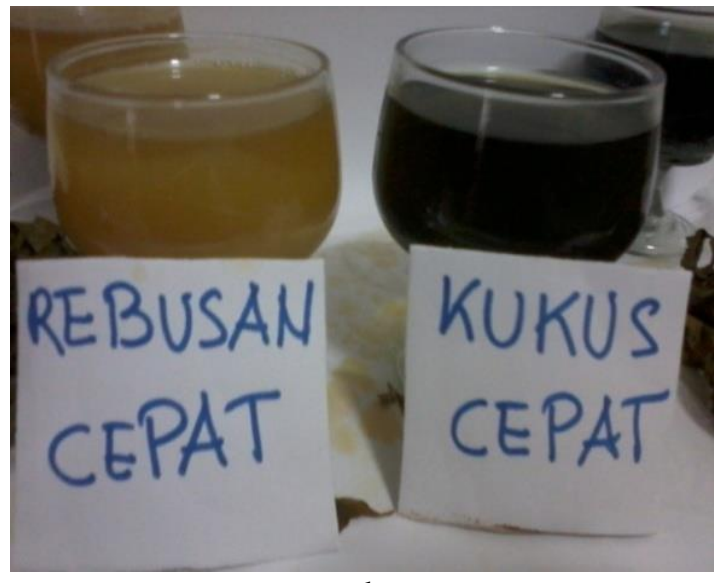

d

Gambar 4. Berbagai pengamatan fisik terhadap air sisa pada perlakuan rebusan dan pengukusan

\section{Analisa total padatan}

Rerata total padatan daun beluntas segar berkisar antara 1,969 g/100 g sampai $5,489 \mathrm{~g} / 100 \mathrm{~g}$. Pengaruh berbagai proses pengolahan terhadap total padatan daun beluntas ditunjukan pada Gambar 18. Rerata total padatan yang terkandung dalam daun beluntas segar berkisar antara 3,836 g/100 g dan 4,206 g/100 g. Dengan demikian dapat dilihat bahwa daun beluntas hijau tua mempunyai nilai total padatan yang berbeda nyata dengan.

Sedangkan pada produk hasil olahannya, total padatan cenderung menurun. Hasil analisa ragam memperlihatkan bahwa perlakuan proses pengolahan pada daun beluntas memberikan pengaruh yang berbeda nyata terhadap nilai total padatan padatan. Rerata total padatan daun beluntas setelah proses pengolahan dapat dilihat pada Tabel 4 .
Tabel 4. Rerata total padatan daun beluntas akibat pengolahan

\begin{tabular}{lc}
\hline \multicolumn{1}{c}{ Perlakuan } & nilai tengah \\
\hline Segar & $5,488512(\mathrm{de})$ \\
Rebus Cepat & $4,513768(\mathrm{~cd})$ \\
Rebus Lambat & $2,6177(\mathrm{~b})$ \\
Kukus Cepat & $5,207708(\mathrm{de})$ \\
Kukus Lambat & $4,330065(\mathrm{bc})$ \\
Goreng & $1,969025(\mathrm{a})$ \\
\hline BNJ 5\% $=0,81355329596522$
\end{tabular}

Keterangan: rerata yang didampingi huruf yang berbeda menunjukkan pengaruh yang berbeda nyata pada taraf $(\alpha=0,05)$

Nilai total padatan terendah ditunjukkan oleh kukus daun beluntas, yakni $1,969 \mathrm{~g} / 100 \mathrm{~g}$. Sedangkan total padatan tertinggi tampak pada pasta daun beluntas segar, yakni sebesar 5,4885 g/100 g. Dalam pembuatan kukus daun beluntas, daun dihancurkan agar proses ekstraksi lebih 
mudah dan cepat. Dengan memanfaatkan gaya gravitasi, cairan ekstrak ditampung. Sedangkan pemisahan sampah dilakukan dengan memanfaatkan gaya sentripetal. Dengan demikian ampas tidak bercampur kembali dengan cairan estrak dan kukus yang dihasilkan mempunyai kualitas baik.

Ekstraksi kukus daun diperlukan untuk menjamin efektivitas penyimpanan dan mencegah kehilangan hal-hal yang tidak diperlukan serta meminimalkan zat-zat yang tak diperlukan (Abulude et al., 2007).

\section{Uji kualitatif komponen kimiawi daun beluntas}

Uji kualitatif komponen kimiawi pada daun beluntas dilakukan untuk menentukan ada tidaknya komponen kimiawi tertentu dalam daun tersebut. Beberapa jenis komponen kimiawi dapat diuji secara sederhana tanpa perlakuan khusus sebagai tahap pendahuluan misalnya saponin, tanin dan lain-lain. Namun, ada pula beberapa jenis komponen kimiawi yang dalam pengujiannya memerlukan perlakuan pendahuluan antara lain alkaloid, polifenol, antrauinon dan lain sebagainya. Berikut hasil pengujian komponen kimiawi daun beluntas secara kualitatif.

\section{Deteksi alkaloid}

Pada pengujian ini, diperlukan tahap ekstraksi serta adanya reagen khusus pendeteksi alkaloid, yakni reagen Dargendroff. Hasil uji menunjukkan reaksi positif apabila setelah penetesan reagen Dargendroff muncul endapan berwarna merah kecokelatan/oranye (Kristanti dan Aminah, 2001). Gambar hasil deteksi alkaloid pada daun beluntas dan beberapa produk hasil pengolahannya dapat dilihat pada halaman berikut. antara warna reagen Dargendroff, akuades dan warna hasil uji. Seluruh ekstrak daun beluntas menunjukkan reasi positif dalam uji ini dengan terbentuknya endapan alaloid. Endapan ini merupakan reaksi antara reagen Dargendroff dengan partikel alkaloid. Meskipun semua menunjukkan hasil positif namun masingmasing ekstrak menunjukkan perbedaan. Estrak daun beluntas dari varietas yang berbeda menunjukkan hasil yang berbeda pula. daun beluntas hijau tua menunjukkan endapan yang lebih pekat dibandingkan dengan daun beluntas hijau muda.

Pada beberapa produk hasil pengolahan daun beluntas, endapan sangat sedikit terlihat pada ekstrak daun beluntas yang diberi perlakuan pemanasan, yakni perebusan. Sedangkan endapan yang paling pekat dan lebih banyak nampak pada daun beluntas segar dan kukus daun beluntas. Muchtadi (1986) menyatakan bahwa komponen kimia dalam tanaman dapat dipengaruhi oleh beberapa faktor antara lain perbedaan varietas, keadaan iklim, tempat tumbuh, cara pemeliharaan tanaman, cara pemanenan, dan kematangan pada waktu panen dan kondisi penyimpanan setelah panen.

\section{Deteksi polifenol}

Seperti pada uji alkaloid, pengujian polifenol ini juga memerlukan tahap ekstraksi. Uji menunjukkan reaksi positif jika setelah penambahan larutan besi (III) klorida timbul warna warna hijau, hijau kekuningan, kemerahan, ungu, biru, atau hitam yang kuat (Harborne, 1996). Berikut gambar hasil deteksi polifenol pada ekstrak daun beluntas dan beberapa produk hasil pengolahannya.

Berdasarkan gambar-gambar hasil uji deteksi polifenol, dapat dinyatakan bahwa ekstrak daun beluntas menunjukkan reaksi positif dengan terbentuknya warna kuning keemasan. Berdasarkan intensitas warna dapat dilihat perbedaan hasil uji masingmasing ekstrak. daun beluntas hijau tua menunjukkan warna yang lebih kuning dibandingkan dengan daun beluntas hijau muda.

Pada beberapa produk hasil pengolahan, daun beluntas yang diberi perlakuan pemanasan (perebusan) menunjukkan warna yang lebih terang (kuning jernih). Sedangkan warna yang lebih pekat nampak pada kukus daun beluntas segar. Hal ini sesuai dengan hasil penelitian Melo et al. (2006) bahwa daun beluntas mengandung senyawa fenol dan flavonol namun dalam jumlah yang sangat sedikit jika dibandingkan dengan jenis sayur-sayuran lain di negara Brazil. 


\section{Deteksi komponen kimiawi lainnya}

Untuk beberapa uji kualitatif komponen kimiawi lainnya, daun beluntas menunjukkan reaksi positif dan negatif. Uji tersebut meliputi deteksi saponin, flavonoid, tannin dan antrakuinon.

Uji terhadap keberadaan senyawa flavonoid dan tannin menunjukkan hasil positif, namun terhadap senyawa saponin dan antrakuinon menunjukkan hasil negative. Meskipun dalam literatur (Melo et al., 2006) dinyatakan bahwa daun beluntas mengandung senyawa fenol dan flavonol, namun dalam jumlah yang sangat sedikit. Selain itu, penelitian tersebut dilakukan pada daun beluntas yang berasal dari Brazil. Sedangkan Muchtadi (1988) juga menyatakan bahwa komponen kimia dalam tanaman dapat dipengaruhi oleh beberapa faktor antara lain perbedaan varietas, keadaan iklim, tempat tumbuh, cara pemeliharaan tanaman, cara pemanenan, dan kematangan pada waktu panen serta kondisi penyimpanan setelah panen. Hasil selengkapnya uji kwalitatif terhadap senyawa-senyawa tersebut tersaji pada Tabel 5 . berikut ini.

Tabel 5. Hasil uji kwanlitatif senyawa fitokimia daun beluntas segar

\begin{tabular}{clc}
\hline No & \multicolumn{1}{c}{ Deteksi } & Hasil \\
\hline 1. & Alkaloid & + \\
2. & Polifenol & + \\
3. & Flavonoid & + \\
4. & Saponin & - \\
5. & Tanin & + \\
6. & Antrakuinon & - \\
\hline
\end{tabular}

Uji kuantitatif komponen kimiawi daun beluntas

\section{Analisa proksimat}

Hasil rerata analisa proksimat untuk kadar air, kadar karbohidrat, lemak, protein dan kadar abu tersaji pada tabel di bawah ini:

Tabel 6 Rerata analisa proksimat (\%) daun beluntas akibat pengolahan

\begin{tabular}{llccccc}
\hline No & Perlakuan & Kadar air & karbohidrat & Lemak & Protein & Abu \\
\hline 1. & Segar & 84,69 & 8.79 & 0,21 & 4,04 & 2,27 \\
2. & Rebus cepat & 91,10 & 5,13 & 0,18 & 2,77 & 0,82 \\
3. & Rebus lambat & 92,12 & 4,44 & 0,15 & 2,37 & 0,92 \\
4. & Kukus cepat & 87,12 & 7,57 & 0,23 & 3,25 & 1,83 \\
5. & Kukus lambat & 87.39 & 7,57 & 0,18 & 3,08 & 1,78 \\
6. & Goreng & 6,79 & 15,00 & 65,79 & 7,36 & 5,06 \\
\hline
\end{tabular}

Analisa proksimat yang dilakukan terhadap daun beluntas akibat berbagai perlakuan pengolahan memperlihatkan bahwa dengan digoreng cepat diperoleh kadar karbohidrat, lemak, protein dan kadar abu yang tertinggi, sedang terendah diperoleh jika beluntas diolah dengan direbus, baik secara cepat maupun lambat.

\section{Analisa vitamin $\mathbf{C}$}

Kandungan vitamin $\mathrm{C}$ tertinggi didapat pada perlakuan pengukusan cepat dan lebih tinggi dari daun yang segar. Terdapat kendala pengukuran vitamin $\mathrm{c}$ pada hasil perlakuan penggorengan yang disebabkan oleh adanya kandungan lemak yang tinggi pada daun beluntas hasil perlakuan tersebut.

Pengukuran vitamin $\mathrm{C}$ terhadap sisa air rebusan menunjukkan bahwa kandungan vitamin $\mathrm{C}$ tertinggi terdapat pada air rebusan dengan waktu lama, sedang terendah terdapat pada air kukus dengan waktu cepat. Hal ini memberikan kesimpulan bahwa kehilangan vitamin $\mathrm{C}$ bisa terjadi pada pengolahan dengan direbus dalam waktu lama, sedang kehilangan vitamin $\mathrm{C}$ dalam jumlah kecil bila diolah dengan pengukusan yang cepat.

\section{Analisa kandungan klorofil}

Kandungan klorofil tertinggi didapat pada perlakuan perebusan cepat dan terendah pada bahan yang digoreng dengan waktu lama. Terlihat pula bahwa warna daun beluntas dengan direbus cepat paling hijau dibanding perlakuan yang lain. Hal ini sesuai dengan hasil pengamatan pada sisa air pengukusan yang berwarna hijau, sedang sisa air rebusan berwarna kekuningannya makin. 
Makin lama dilakukan pengukusan maka sisa air makin berwarna hijau pekat.

Pengukuran klorofil pada berbagai teknik pengolahan terhadap daun beluntas memberikan kesimpulan bahwa kehilangan klorofil bisa terjadi pada pengolahan dengan di kukus dalam waktu lama, sedang kehilangan klorofil dalam jumlah kecil bila diolah dengan perebusan cepat.

Tabel 7. Rerata kandungan vitamin $\mathrm{C}$ dan klorofil daun beluntas pengolahan

\begin{tabular}{llcc}
\hline No & Perlakuan & Vitamin C $(\mathbf{m g} / \mathbf{1 0 0}$ gr $)$ & Klorofil $\mathbf{( m g / g )}$ \\
\hline 1. & Segar & 62,72 & 318,75 \\
2. & Rebus cepat & 94,65 & 175,54 \\
3. & Rebus lambat & 92,12 & 162,93 \\
4. & Kukus cepat & 145,90 & 148,21 \\
5. & Kukus lambat & 134,84 & 121,37 \\
6. & Goren & --- & 11,51 \\
\hline
\end{tabular}

\section{Total alkaloid}

Pada daun beluntas segar dan beberapa produk olahannya diketahui adanya kandungan alkaloid. Namun, belum diketahui jenis-jenis dari alkaloid tersebut. Kandungan senyawa kimia ini perlu diketahui karena meski secara umum bersifat racun namun dalam beberapa hal senyawa ini digunakan sebagai obat. Karena belum diketahuinya jenis alkaloid yang terkandung dalam daun beluntas maka penentuan total alkaloid dilakukan dengan metode Thin Layer Chromatography (TLC). Meskipun metode ini tergolong sederhana, namun masih dapat digunakan untuk menentukan kandungan alkaloid secara kasar.

Rerata total alkaloid estrak daun beluntas berkisar antara 3,297 mg/g sampai $3,5 \mathrm{mg} / \mathrm{g}$. Pengaruh berbagai proses pengolahan terhadap total alkaloid daun beluntas ditunjukan pada Gambar 13. Rerata total alkaloid yang terkandung dalam daun beluntas segar berkisar antara $3,4 \mathrm{mg} / \mathrm{g}$ dan $3,5 \mathrm{mg} / \mathrm{g}$. Ekstrak dari pasta segar daun beluntas hijau tua menunjukkan nilai yang paling tinggi, yakni $3,5 \mathrm{mg} / \mathrm{g}$ sedangkan menunjukkan nilai yang lebih rendah $(3,4$ $\mathrm{mg} / \mathrm{g}$ ). Perbedaan daun beluntas menunjukkan nilai total alkaloid yang berbeda nyata.

Sedangkan pada produk hasil pengolahan beluntas, nilai total alkaloid terendah ditunjukkan oleh ekstrak pasta daun beluntas rebus, yakni 3,297 mg/g. Sedangkan total alkaloid tertinggi tampak pada ekstrak pasta daun beluntas segar, yakni sebesar 3,5 $\mathrm{mg} / \mathrm{g}$. Dengan demikian dapat dinyatakan bahwa pada produk hasil olahan beluntas total alkaloidnya cenderung menurun. Hasil analisa ragam memperlihatkan bahwa perlakuan proses pengolahan pada daun beluntas memberikan pengaruh yang sangat nyata terhadap nilai total alkaloid. Rerata total alkaloid daun beluntas setelah proses pengolahan dapat dilihat pada tabel 8 .

Tabel 8. Nilai rerata total alkaloid ekstrak daun beluntas akibat pengolahan

\begin{tabular}{lc}
\hline \multicolumn{1}{c}{ Perlakuan } & Notasi \\
\hline Segar & $3,4(\mathrm{bc})$ \\
Rebus Cepat & $3,29(\mathrm{a})$ \\
Rebus Lambat & $3,4(\mathrm{~d})$ \\
Kukus Cepat & $3,5(\mathrm{e})$ \\
Kukus Lambat & $3,30(\mathrm{~b})$ \\
Goreng & $3,45(\mathrm{e})$ \\
\hline BNJ 5\%=0,042876869357474
\end{tabular}

Keterangan: rerata yang didampingi huruf yang berbeda menunjukkan pengaruh yang nyata pada taraf $(\alpha=0,05)$

Proses pengolahan daun beluntas berpengaruh sangat nyata terhadap kandungan alkaloid. Dalam hal ini perlakuan pemanasan menunjukkan penurunan kandungan alkaloid paling tinggi. Hal ini disebabkan alkaloid bersifat peka terhadap panas seperti pernyataan Sastrohamidjojo (1996) bahwa kebasaan alkaloid menyebabkan senyawa tersebut sangat mudah mengalami dekomposisi, terutama oleh panas dan sinar hanya dengan adanya 
oksigen. Hasil dari reaksi ini sering berupa N-oksida.

Sedangkan dalam kukus daun beluntas penurunan kandungan alkaloid cukup rendah. Hal ini disebabkan pada proses pembuatan kukus daun tidak dilakukan proses pemanasan sehingga kandungan gizinya tidak banyak mengalami kerusakan. Selain itu, kukus daun merupakan ekstrak dari daun sehingga prosentase zat gizi dan senyawa yang larut air lebih tinggi dibandingkan daun secara utuh.

\section{Total fenol}

Analisa fenol ekstrak daun beluntas dilakukan dengan metode Folin-Ciocalteu. Metode ini bertujuan untuk menentukan kandungan fenolik dalam ekstrak daun secara kuantitatif. Prinsipnya didasarkan pada kemampuan reduksi senyawa fosfomolibdat- fosfotungstat dari reagen folin dengan membentuk warna biru sehingga dapat ditentukan secara spektrofotometri. Semakin tinggi (pekat) intensitas warna larutan menunjukkan kadar total fenol dalam sampel semakin besar. Total fenol menurut prosedur ini dapat dihasilkan dari sejumlah senyawa fenol, seperti fenol sederhana (derivat asam hidroksi benzoat dan hidroksi sinamat), polifenol seperti tanin terhidrolisis dan terkondensasi serta flavonoid seperti pada umumnya (Suryanto et al. dalam Fransisca, 2007).

Rerata total fenol ekstrak daun beluntas berkisar antara 34,104 mg/g sampai 47,862 $\mathrm{mg} / \mathrm{g}$. Pengaruh berbagai proses pengolahan terhadap total fenol daun beluntas ditunjukan pada grafik berikut.

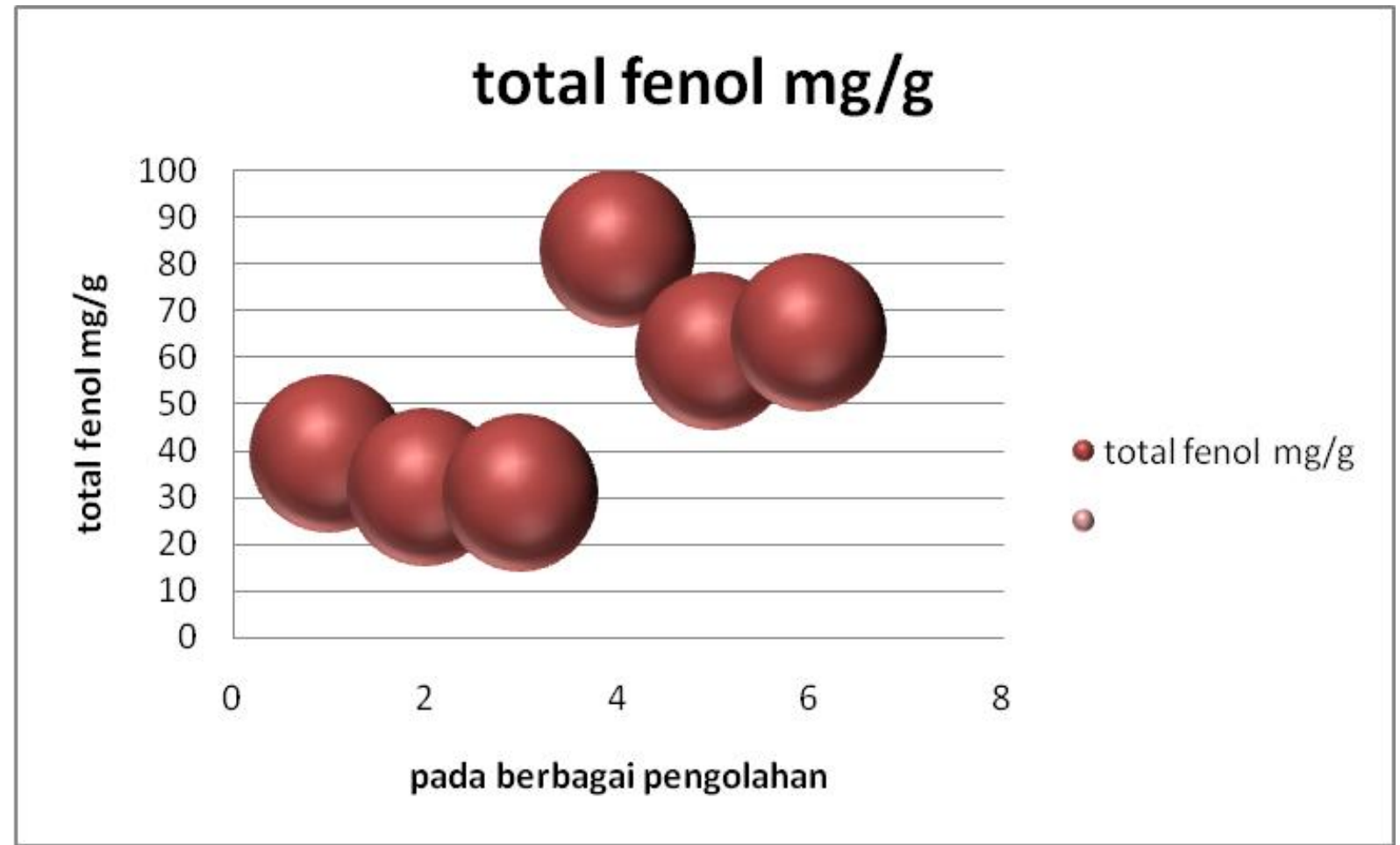

Gambar 5. Grafik rerata total fenol daun beluntas akibat pengolahan

Rerata total fenol yang terkandung dalam daun beluntas segar berkisar antara $39,24 \mathrm{mg} / \mathrm{g}$ hingga 47,862 mg/g. Ekstrak dari pasta segar daun beluntas hijau tua menunjukkan nilai yang paling tinggi, yakni 47,862 mg/g sedangkan menunjukkan nilai yang lebih rendah $(39,24 \mathrm{mg} / \mathrm{g})$. Perbedaan daun beluntas menunjukkan nilai total fenol yang berbeda nyata. Dengan demikian dapat dilihat bahwa daun beluntas hijau muda mempunyai kandungan fenol yang berbeda nyata dengan.

Manach et al. (2004) menjelaskan bahwa perbedaan konsentrasi (polifenol) pada beberapa daun yang berasal dari pohon yang sama atau pada beberapa bagian daun yang berasal dari satu daun dikarenakan intensitas cahaya yang diperolehnya, 
khususnya polifenol yang proses biosintesisnya distimulasi oleh cahaya, seperti flavanol. Sedangkan Cheynier (2005) menyatakan bahwa dalam satu spesies, mungkin ditemukan beragam jenis polifenol. Hal ini dikarenakan faktor genetis, kondisi lingkungan serta tahap pertumbuhan dan pematangan.

Tabel 9. Nilai rerata total fenol ekstrak daun beluntas akibat pengolahan

\begin{tabular}{lc}
\hline 9 Perlakuan & Notasi \\
\hline Segar & $39,135006(\mathrm{bc})$ \\
Rebus Cepat & $32,10397(\mathrm{a})$ \\
Rebus Lambat & $30,95649(\mathrm{ab})$ \\
Kukus Cepat & $83,113067(\mathrm{e})$ \\
Kukus Lambat & $61,0752(\mathrm{~d})$ \\
Goreng & $65,59026(\mathrm{e})$ \\
\hline BNJ 5\%=2,24995346192888
\end{tabular}

Keterangan: rerata yang didampingi huruf yang berbeda menunjukkan pengaruh yang nyata pada taraf $(\alpha=0,05)$

Pada produk hasil olahannya, total fenol cenderung menurun. Nilai total fenol terendah ditunjukkan oleh ekstrak pasta daun beluntas rebus, yakni $34,104 \mathrm{mg} / \mathrm{g}$. Sedangkan total fenol tertinggi tampak pada ekstrak pasta daun beluntas segar, yakni sebesar 47,862 mg/g. Hasil analisa ragam menunjukkan bahwa perlakuan proses pengolahan pada daun beluntas memberikan pengaruh yang sangat nyata terhadap nilai total fenol. Rerata total fenol daun beluntas setelah proses pengolahan dapat dilihat pada tabel 9.

Penurunan nilai total fenol akibat proses perebusan (pemanasan) lebih tinggi dibandingkan produk kukus. Hal ini sesuai dengan pernyataan Cheynier (2005) bahwa semua senyawa polifenol merupakan senyawa yang sangat tidak stabil yang mengalami sejumlah reaksi selama proses pengolahan pangan dan penyimpanannya. Perubahan yang terjadi diasosiasikan dengan proses pengolahan yang meliputi ekstraksi selektif senyawa tertentu dengan kukus atau teknologi pembuatan anggur serta penghilangan beberapa bagian (seperti kulit dan biji) sebelum dikonsumsi.
Polifenol adalah senyawa yang sangat reaktif dan merupakan substrat yang bagus untuk berbagai enzim, seperti polifenoloksidase, peroksidase, glikosidase dan esterase. Mereka mengalami sejumlah reaksi kimia dan enzimatis selama penyimpanan pascapanen dan selama pengolahan. Kecepatan reaksi tersebut di atas tergantung pada jumlah prekursor fenol dan juga beberapa faktor lainnya, meliputi konsentrasi senyawa nonfenolik (misal aldehid), ketersediaan oksigen dan adanya katalis oksidasi, $\mathrm{pH}$ serta temperatur. Sedangkan reaksi kimia terjadi secara serempak dan berangsur-angsur merata saat aktivitas enzimatis menurun (Cheynier, 2005).

Komposisi polifenol makanan dan minuman berbahan dasar tumbuhan tergantung pada bahan baku yang digunakan, proses ekstraksi yang dilakukan dan selanjutnya reaksi kimia dan biokimia polifenol tersebut (Cheynier, 2005).

Hasil penelitian menunjukkan bahwa perebusan memicu hilangnya vitaminvitamin yang larut air seperti vitamin $C$ dan folat, se daun vitamin $\mathrm{B}$ yang sangat penting bagi tubuh. Hasil penelitian lain juga menunjukkan bahwa senyawa antioksidan tertentu seperti fitokimia juga hilang karena perebusan dalam air. Namun jika proses pemasakan menggunakan air secara minimal maka diperoleh hasil kehilangan vitamin dan senyawa fitokimia yang tidak signifikan (Collins, 2007).

Lebih rendahnya nilai total fenol kukus dibandingkan dengan pasta daun beluntas segar disebabkan proses kukus tidak dapat mengekstrak cairan dalam daun secara sempurna sehingga masih ada zat gizi maupun senyawa lain yang masih tertinggal di dalam ampas. Konsentrasi polifenol dalam produk hasil industri lebih rendah dibanding produk segar (Cheynier, 2005).

Ekstrak n-heksana daun beluntas yang di kukus, pada uji KLT dengan penampak noda anisaldehida asam sulfat menunjukkan adanya noda berwarna ungu dan merah ungu. Noda-noda tersebut menunjukkan bahwa 
daun beluntas yang di kukus mengandung senyawa golongan terpenoid.

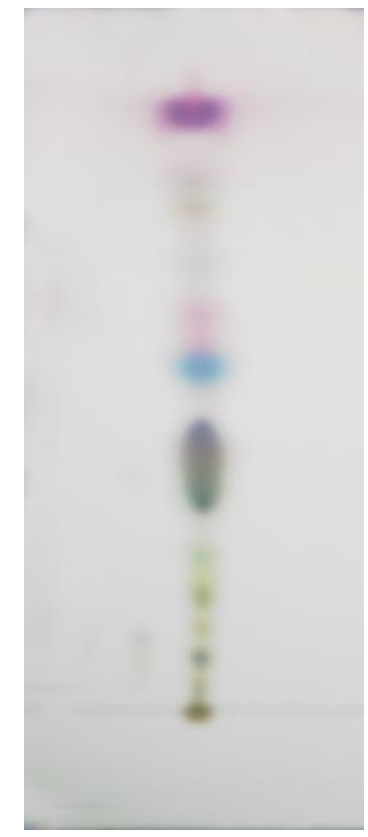

Gambar 6. Profil kromatogram KLT ekstrak n-heksana daun beluntas yang di kukus dengan penampak noda anisalhedida asam sulfat

\section{KESIMPULAN}

Berdasarkan hasil uji kualitatif dapat dinyatakan bahwa daun beluntas mengandung senyawa fitokimia antara lain alkaloid dan polifenol, flavonnoid dan tannin Sementara saponin dan antrakuinon tidak ditemukan dalam ini. Sedangkan menurut hasil analisa kuantitatif, kadar polifenol daun beluntas yang paling tinggi adalah apabila diolah dengan cara pengukusan cepat dalam suhu tinggi.

Berdasarkan kadar polifenol yang diperoleh, yang di kukus merupakan produk olahan daun beluntas yang paling baik. Produk ini menunjukkan kadar polifenol sebesar $83,113 \mathrm{mg} / \mathrm{g}$ dengan nilai kecerahan (L*) $(46,400)$ dan warna hijau $(a)(2,967)$. Sedangkan pada , produk segar menunjukkan kadar polifenol sebesar 39,135 mg/g dengan nilai kecerahan $\left(\mathrm{L}^{*}\right)(46,067)$ dan warna hijau (a) (2). Kadar air masing-masing produk olahan tidak berbeda nyata. Sementara itu, varietas dan proses pengolahan tidak berpengaruh nyata terhadap warna $(b)$.

Ekstrak n-heksana daun beluntas yang di kukus, pada uji KLT dengan penampak noda anisaldehida asam sulfat menunjukkan adanya noda berwarna ungu dan merah ungu. Noda-noda tersebut menunjukkan bahwa daun beluntas yang di kukus mengandung senyawa golongan terpenoid. Sedangkan saran dari penelitian ini perlu ada identifikasi lebih lanjut tentang jenis dan kadar alkaloid serta komponen senyawa lain yang terkandung dalam daun beluntas sehingga dapat diketahui peranannya bagi kesehatan.

\section{DAFTAR PUSTAKA}

Apriyantono, A.D, Fardiaz, N.L., Puspitasari, Sadarnawati \& S. Bidiyanto. (1989). Analisa pangan. Penerbit IPB Press. Bogor.

Arsiningtyas, I. S., Gunawan-Puteri, M. D., Kato, E., \& Kawabata, J. (2014). Identification of $\alpha$-glucosidase inhibitors from the leaves of Pluchea indica (L.) Less., a traditional Indonesian herb: promotion of natural product use. Natural product research, 28(17), 1350-1353. https://doi.org/10.1080/14786419.2014. 904306

Blumenthal, H. (2008). What affects the colour and texture of cooked vegetables?.

http://www.rsc.org/education/teachers/l earnnet/kitchenchemistry/docs/SS06b.p df. Diakses pada tanggal 11 November 2008. 07.09

Buapool, D., Mongkol, N., Chantimal, J., Roytrakul, S., Srisook, E., \& Srisook, K. (2013). Molecular mechanism of anti-inflammatory activity of pluchea indica leaves in macrophages raw 264.7 and its action in animal models ofinflammation. Journal of ethnopharmacology, 146(2), 495-504. https://doi.org/10.1016/j.jep.2013.01.014

Cheynier, V. (2005). Polyphenols in foods are more complex than often thought. 
American Journal of Clinial Nutrition, 81(1), 223S-229S

Dauthy, M.E. (1995). Fruit and vegetable processing. FAO Agricultural Services Bulletin No.119. Food and Agriculture Organization of The United Nations. Rome

Departemen Pertanian. (2007). Daftar varietas yang sudah dilepas. Direktorat Perbenihan dan Sarana Poduksi. Direktorat Jenderal Hortikultura. Departemen Pertanian

Ekowahyuni, L.P. (2002). Fenomena vivipary daun beluntas (Pluchea indica,. Jacq Swartz) varietas lokal Desa Barukupa Bawah Cipanas. Makalah Falsafah Sains (PPs 702) Program Pasca Sarjana/S3. Institut Pertanian Bogor.

Hafsari, A. R., Cahyanto, T., Sujarwo, T., \& Lestari, R. I. (2015). Uji aktivitas antibakteri ekstrak daun beluntas (pluchea indica (1.) less.) terhadap propionibacterium acnes penyebab jerawat. Jurnal Istek, 9(1), 141-160

Hanani, E., Abdul M., \& Ryani, S. (2005). Identifikasi senyawa antioksidan dalam spons callyspongia sp dari kepulauan seribu. Majalah Ilmu Kefarmasian, 2(23), 127-133.

Kongkiatpaiboon, S., Chewchinda, S., \& Vongsak, B. (2018). Optimization of extraction method and hplc analysis of six caffeoylquinic acids in Pluchea indica leaves from different provenances in Thailand. Revista Brasileira de Farmacognosia, 28(2), 145-150.

Kristanti, A. N., \& Nanik, S.A. (2001). Usaha pemanfaatn alkaloid total dari kulit batang tanaman saccopetalum harsfiedtii sebagai biolarvasida. Jurnal Penelitian Medika Eksakta, 2(1), 54-60

Manske, R.H.F., \& Holmes, H.L. (1950). The alkaloids cemistry and physicology. Academic Press Ltd. London

Melo, Enayde de A., Vera L. A, . Galvao de Lima, \& Maciel, M.I.S. (2006). Polyphenol, ascorbic acid and total carotenoid contents in common fruits and vegetables. Brazilian Journal of Food Technology, 9(2), 89-94

Muchtadi, D. (1992). Fisiologi pasca panen tanaman obat dan buah-buahan. Departemen Pendidikan dan Kebudayaan Direktorat Jenderal Pendidikan Tinggi Pusat Antar Universitas Pangan dan Gizi. Institut Pertanian Bogor. Bogor

Neamsuvan, O., \& Ruangrit, T. (2017). A survey of herbal weeds that are used to treat gastrointestinal disorders from southern Thailand: Krabi and Songkhla provinces. Journal of ethnopharmacology, 209, 318-327. https://doi.org/10.1016/j.jep.2017.06.03 9

Nopparat, J., Nualla-Ong, A., \& Phongdara, A. (2019). Ethanolic extracts of Pluchea indica (L.) leaf pretreatment attenuates cytokine-induced $\beta$-cell apoptosis in multiple low-dose streptozotocin-induced diabetic mice. PloS one, 14(2), e0212133. https://doi.org/10.1371/journal.pone.02 12133

Noridayu, A. R., Hii, Y. F., Faridah, A., Khozirah, S., \& Lajis, N. (2011). Antioxidant and antiacetylcholinesterase activities of Pluchea indica Less. International Food Research Journal, 18(3). 925929.

Pramanik, K. C., Bhattacharya, P., Biswas, R., Bandyopadhyay, D., Mishra, M., \& Chatterjee, T. K. (2006). Hypoglycemic and antihyperglycemic activity of leaf extract of Pluchea indica Less. Orient Pharm Exp Med, 6, 232-236.

Rukmana, R. (1999). Budidaya Tanaman daun beluntas (Pluchea indica,. Jacq Swartz). Penerbit Kanisius. Yogyakarta

Setiawan, D. (2008). 36 Resep tumbuhan obat untuk menurunkan kolesterol. Penerbit Penebar Swadaya. Edisi Revisi. Jakarta

Sirichaiwetchakoon, K., Lowe, G. M., Thumanu, K., \& Eumkeb, G. (2018). The effect of Pluchea indica (L.) less. 
tea on Adipogenesis in 3T3-L1 adipocytes and lipase activity. Evidence-Based Complementary and Alternative Medicine, 2018(1), 1-13. https://doi.org/10.1155/2018/4108787

Srimoon, R., \& Ngiewthaisong, S. (2015). Antioxidant and antibacterial activities of Indian marsh fleabane (Pluchea indica (L.) Less). Asia-Pacific Journal of Science and Technology, 20(2), 144154.

Srisook, K., Buapool, D., Boonbai, R., Simmasut, P., Charoensuk, Y., \& Srisook, E. (2012). Antioxidant and anti-inflammatory activities of hot water extract from Pluchea indica Less. herbal tea. Journal of Medicinal Plants Research, 6(23), 4077-408. https://doi.org/10.5897/JMPR12.773

Suriyaphan, O. (2014). Nutrition, health benefits and applications of Pluchea indica (L.) Less leaves. Mahidol University Journal of Pharmaceutical Sciences, 41(4), 1-10.

Vessal M., Akmali, M., \& Bambaee-Row, N. (2000). Thin layer chromatographic detection of steroid and alkaloid glycosides in an ethanolic extract of winter cherry (Physalis alkekengi) Fruits. Comp Biochem Physiol 1995(111B)675- 806.

Vongsak, B., Kongkiatpaiboon, S., Jaisamut, S., \& Konsap, K. (2018). Comparison of active constituents, antioxidant capacity, and $\alpha$-glucosidase inhibition in Pluchea indica leaf extracts at different maturity stages. Food Bioscience, 25, 68-73. https://doi.org/ 10.1016/j.fbio.2018.08.006
Widyawati, P. S., Budianta, T. D. W., Kusuma, F. A., \& Wijaya, E. L. (2014). Difference of solvent polarity to phytochemical content and antioxidant activity of Pluchea indicia less leaves extracts. International Journal of Pharmacognosy and Phytochemical Research, 6(4), 850-855.

Widyawati, W., Jans, S., Bor, H. H., van Dillen, J., \& Lagro- Janssen, A. L. (2015). The effectiveness of a new model in managing pregnant women with iron deficiency anemia in Indonesia: a nonrandomized controlled intervention study. Birth, 42(4), 337-345. https://doi.org/10.1111/birt. 12181

Yuwono, S., \& Susanto, T. (1998). Pengujian fisik pangan. Jurusan Teknologi Hasil Pertanian. Fakultas teknologi Pertanian. Universitas Brawijaya. Malang. 